\title{
THE EFFECTIVENESS OF PARALLEL WRITING TO IMPROVE STUDENTS WRITING NARRATIVE TEXT
}

\author{
Cep Bahrul Ulum¹, Surya Darmawan² \\ ${ }^{1}$ IKIP Siliwangi \\ ${ }^{2}$ IKIP Siliwangi \\ 1eppbahru19@gmail.com, ${ }^{2}$ suryadarmawan07@gmail.com
}

\begin{abstract}
English as a global language in all over the world seems to be a priority for people to learn. It is because as social creatures, people absolutely need to communicate in their everyday life in order to socialize or to express their thought, feeling, understanding, opinion, critic, and everything that they want to share to others. English becomes language that should be learn by all students in Indonesia. It has four language skills to be mastered; listening, speaking, reading and writing. However, during the time, most of students have difficulties in mastering writing skill. Those difficulties come because the process of writing requires an entirely different set of competencies and is fundamentally different from speaking (Douglas \& Heekyeong, 2015). Therefore, regarding to those difficulties, this research offered one of the language teaching techniques which hopefully can be applied as one of alternatives way in teaching to improve students' writing skill especially in writing narrative text. Moreover, the writer comes up with a research entitled; The Effectiveness of Parallel Writing Technique to Improve Students Writing Skill in Narrative Text. This study was conducted at one of junior high school in West Bandung involving 30 students as the sample. Then, by using pre-test as post-test as the main instruments calculated with t-test statistical computation, it can be seen that there is significant improvement coming from the students after they got parallel writing technique. Therefore, it is hoped that it can be beneficial for the improvement of writing skill.
\end{abstract}

Keywords: Parallel Technique, Students Writing, Narrative Text.

\section{INTRODUCTION}

There are four language skills to be mastered; listening, speaking, reading and writing. By mastering four language skills, students are expected to be able to communicate fluently in English both spoken and written. But, many students had difficulties in mastering writing skill. Sometimes they may understand what the teacher mean but they can not deliver it well in the written form. Besides, other difficulties that are faced by the students in mastering writing skill are, firstly the process of writing requires an entirely different set of competencies and is fundamentally different from speaking (Douglas \& Heekyeong, 2015). Secondly, written products are often the result of thinking, drafting, and revising procedures that require specialized skills, skills that not every speaker develops naturally (Douglas \& Heekyeong, 2015). Thirdly, many students either think or say that they cannot, or do not want to write because they lack of confident, think it is boring or believe they have 'nothing to say' (Harmer Jeremy, 2015).

Therefore, regarding to those difficulties, this research will offer one of the language teaching techniques which hopefully can be applied as one of alternatives way in teaching in improving students' writing skill especially in writing narrative text. Moreover, the writer comes up with a research entitled; The Effectiveness of Parallel Writing Technique to Improve Students Writing Skill in Narrative Text at One of Junior High School in West Bandung. 
English curriculum is designed according to the government regulation in the sense that the curriculum has to be competence-based and that at the end the day learners are expected to communicate in English as one of their life skills and that they are expected to be able to handle written text not only for pursuing further studies, but also for learning independently in order to be independent members of community (Agustien, 2006). In other words, learners are encouraged to master writing skill well. Moreover, writing could not be categorized as something that easy to be mastered by them. Students' writers often feel that the act of releasing a written work to an instructor is not unlike putting themselves in front of a firing squad (Douglas \& Heekyeong, 2015). Besides, it is because written language is more conservative than spoken language. It reflects, to a certain extent, the elements and rules that together constitute the grammar of the language (Fraenkal, J. R., Norman E. Wallen, 2012). It means that they need to internalize all of their linguistic competence in the written fore in a more logical order. They need to go to two-step process; first they need to figure out their meaning, then they need to put it into language (Douglas \& Heekyeong, 2015). This becomes worse because the curriculum also states explicitly what kinds of texts are targeted by certain level of schooling based on the learners' communication needs. In this manner, there are several kinds of texts which are targeted in junior high school; they are descriptive, report, news item, and also narrative text. (Agustien, 2006).

Narrative text as one of the texts that are stated in the curriculum becomes a burden for most of students in mastering it. It is because it deals with problematic events which lead to a crisis or turning point of some kind, which in turn finds a resolution (Callaghan, 1989). Therefore, it encourages students to develop their imaginative ability to create a comprehensible narrative text with a standard that stated more in the national curriculum. Moreover, the role of teacher is really needed in order to help them to develop their way of thinking in producing a narrative text. Teacher should try to find the most suitable technique in helping them producing a narrative text.

In deciding the suitable technique, ways of presenting materials and teaching based on the approach used (McGrath, 2016), teacher as a facilitator needs to offer guidance help in helping the students to engage in the thinking process of composing, but in the spirit of respect for students' opinion, must not impose his or her own thoughts on student writing (Douglas \& Heekyeong, 2015). In line with this consideration, there is an alternative technique in teaching narrative text called Parallel Writing technique.

Parallel writing technique is one of techniques which has cooperative learning as the basis of it; it leads the students to work in a small group consisting of four until five members, then they will be given one paragraph which is the first part of a story that the students in the group need to continue the story based on their own opinion and thought (Lie, 2007). The first paragraph that is given by the teacher is considered as a stimulus that can motivate the students to develop their imagination in continuing the story. This stimulation will lead the students to learn and use a rule require them to think, that is, to apply their mental powers in order to distil a workable generative rule from the mass of data presented, and then to analyses the situations where the application of the rule would be useful or appropriate, then learning will be a process in which the students actively tries to make sense of the data and manage to impose some sort of meaningful interpretation or pattern on data, (Hatch, E., \& Farhady, 1982).

Besides, this technique also involves the coordination with the students' partner in the group.

Therefore, in this group work, the students will feel the social dynamic of such a group were of primary importance (Douglas \& Heekyeong, 2015). Moreover, it will encourage them in thinking because they know that their thinking will be a good contribution for their group in 
constructing a comprehensible narrative text. In addition to this consideration, hopefully, by applying this kind of technique in teaching narrative text, the students will be more motivated and enjoy in following the course. Thus, it will help them to improve their writing skill in the future.

\section{METHOD}

Generally, research designs can be classified into three broad research categories: Quantitative research design, Qualitative research design and mixed methods research designs (Creswell, 2014). However, this research used Quantitative Research Design. The researcher selected experimental method which is defined as, what (Fraenkal, J. R., Norman E. Wallen, 2012) argued, "Experimental research or experiment refers to Research in which at least one independent variable is manipulated, other relevant variable are controlled and the effect on one or more dependent variables is observed."

According to (Creswell, 2014), there are three experimental research designs : Pre-experimental design, Quasi-experimental design and True-experimental design. Related to this research the researcher used Pre-experimental design with one group pretest-posttest design that involves three steps. The first step is the students will be given pretest (Q1), the second step is the application of the treatment $(\mathrm{X})$ and the final step is the posttest $(\mathrm{Q} 2)$.

This study employed quantitative one to examine whether or not the parallel writing technique is effective to improve students writing skill especially in writing narrative text. Then, the instruments used were pre-test and post-test. Since there were 30 students involved as the participants, they were given the treatments for four meetings. In the treatments, students were divided into six groups consisting of five members. They were given a paragraph which was part of story. Then, they needed to continue the story by writing it into one paragraph. Moreover, every student in the group got an opportunity in continuing the story. They were free to continue the story based on their creativity and imagination as long as is was related to the paragraph that their friends had been made before in order to make one complete story. To analyze the data gathered the writer used a statistical computation, in order to be able to show whether the result of pre-test and post-test had significant differences or not.

\section{RESULTS AND DISCUSSION}

\section{Results}

The testing of normality was aimed at finding put whether or not the research population was normally distributed. The Kolmogorov-Smirnov and Shapiro -Wilk test reported in the SPSS Explore procedure can be used to test the hypothesis that the distribution is normal, (SPSS recommends these tests only when sample size is less than 50), (Elliott \& Woodward, 2007) and (Field, 2009) also stated that a significant value (Sig. less than .005) indicates a deviation from normality. In addition, (Elliott \& Woodward, 2007) in their study explained that the hypotheses used in testing data normality were as follows : The study was analyzed by using ttest calculation. It was because the data was normal

Table.1 Case Processing Summary

\begin{tabular}{|c|c|c|c|c|c|}
\hline \multicolumn{6}{|c|}{ Cases } \\
\hline \multicolumn{2}{|c|}{ Valid } & \multicolumn{2}{|c|}{ Missing } & \multicolumn{2}{|c|}{ Total } \\
\hline $\mathrm{N}$ & Percent & $\mathrm{N}$ & Percent & $\mathrm{N}$ & Percent \\
\hline
\end{tabular}




\begin{tabular}{|l|l|l|l|l|l|l|}
\hline PRE_TEST & 30 & $100.0 \%$ & 0 & $0.0 \%$ & 30 & $100.0 \%$ \\
POST_TEST & 30 & $100.0 \%$ & 0 & $0.0 \%$ & 30 & $100.0 \%$ \\
\hline
\end{tabular}

Table.2 Tests of Normality

\begin{tabular}{|l|l|l|l|l|l|l|}
\hline & \multicolumn{3}{|l|}{ Kolmogorov-Smirnov } & \multicolumn{3}{l|}{ Shapiro-Wilk } \\
\cline { 2 - 7 } & Statistic & df & Sig. & Statistic & df & Sig. \\
\hline PRE_TEST & .195 & 30 & .005 & .927 & 30 & .042 \\
POST_TEST & .238 & 30 & .000 & .889 & 30 & .005 \\
\hline
\end{tabular}

Based on the table above, we can see the significant on the pretest and post test are higher than .005 in the other word the data was normal. Pre test got significant value .042 and post test got significant .005 .

Table.3 Paired Samples Statistics

\begin{tabular}{|ll|l|l|l|l|}
\hline & & & & Std. Error \\
& & Mean & $\mathrm{N}$ & Std. Deviation & Mean \\
\hline Pair 1 & PRE_TEST & 54.33 & 30 & 17.357 & 3.169 \\
& POST_TEST & 78.83 & 30 & 12.225 & 2.232 \\
\hline
\end{tabular}

Table.4 Paired Samples Correlations

\begin{tabular}{|ll|l|l|l|}
\hline & & $\mathrm{N}$ & Correlation & Sig. \\
\hline Pair 1 & $\begin{array}{l}\text { PRE_TEST } \\
\text { POST_TEST }\end{array}$ & 30 & .784 & .000 \\
\hline
\end{tabular}

\section{Discussion}

In this section the writer discussed the result of collecting and analyzing data based on calculating data in one of junior high school in West Bandung. The data discussed about improving students ability in writing skill. The method of teaching parallel technique used in this research.

Table.5 Paired Samples Test

\begin{tabular}{|c|c|c|c|c|c|c|c|c|c|}
\hline & & \multicolumn{5}{|c|}{ Paired Differences } & \multirow[b]{3}{*}{$\mathrm{t}$} & \multirow[b]{3}{*}{$\mathrm{df}$} & \multirow{3}{*}{$\begin{array}{l}\text { Sig. }(2- \\
\text { tailed })\end{array}$} \\
\hline & & \multirow[b]{2}{*}{ Mean } & \multirow{2}{*}{$\begin{array}{l}\text { Std. } \\
\text { Deviation }\end{array}$} & \multirow{2}{*}{$\begin{array}{l}\text { Std. Error } \\
\text { Mean }\end{array}$} & \multicolumn{2}{|c|}{$\begin{array}{l}95 \% \text { Confidence Interval of } \\
\text { the Difference }\end{array}$} & & & \\
\hline & & & & & Lower & Upper & & & \\
\hline Pair 1 & $\begin{array}{l}\text { PRE_TEST - } \\
\text { POST_TEST }\end{array}$ & -24.500 & 10.856 & 1.982 & -28.554 & -20.446 & $\begin{array}{l}- \\
12.362\end{array}$ & 29 & .000 \\
\hline
\end{tabular}

From the table above, it can be seen that the t observed is 10.856. T table with degree of freedom (df) 29 and level of significant at 5\% (0.05) having value (1.697). Since the significant level is 
1.697, and the t observed is statistically higher (10.856) than $t$ table, it can be said that the null Hypothesis is not supported. And also we see that the significant value less than .005 it means that the null hypothesis is rejected and alternative hypothesis is accepted. It is strengthening by "if the observed $t$ value exceeds the critical $t$ value, the difference between the two means is significantly different, or the alternative hypothesis is accepted" (Kaswan,\&Suprijadi, 2016). Furthermore, the data presented that there was a significant improvement coming from the result of pre-test and post-test. It is proven by the result of t observed (14.437) whish is statistically higher than t table. In the beginning, the students tended to write only 3 until 4 sentences in a paragraph to tell their story. It seemed that they have no idea to develop their story individually. Then, they were given parallel writing as a treatment to write their own story. The treatment was given for four meetings. During the time, they started to get better. It can be seen from the amount of paragraph produced. At first, they tend to write 3 until 4 sentences in a paragraph without any significant idea. In contrast, after having parallel writing treatment for four meetings they could produce 2 until 3 paragraphs with 4 until 5 sentences in each paragraph. The idea presented in the story was also varied and interesting.

\section{CONCLUSION}

The study showed that Parallel Writing technique could improve students' writing skill especially in narrative text. It was proven by the result of the data gathered which was calculated by t-test calculation. Moreover, it was hoped that the parallel writing technique could be one of the alternatives to help students improving their writing skill.

After analyzing the result of the research, the writer proposes some suggestions for English teacher, students and school.

For English teacher, parallel technique in teaching writing skill especially in narrative text can improve the student idea and their expressions also their imagination. It is better for the teacher to be focus on the specific material.

For students, student can increase their focus by using specific material with parallel technique in learning narrative text. This technique can stimulate brain to gain more focus and go into the relaxation level.

For school, this technique can be one of the solution for the school to create some new methods and techniques especially for teaching English as foreign language in narrative subject.

\section{ACKNOWLEDGMENTS}

The Writers would like to say thank you for our supervisor, head of school, teachers, students at one of junior high school in West Bandung, our parents, and all people who supported and prayed us in writing who cannot mention one by one.

\section{REFERENCES}

Agustien, H. I. (2006). Genre-based Approach and The 2004 English Curriculum. A Plenary Paper Presented at UPI National Seminar, 2, 27.

Callaghan, M. (1989). A Brief Introduction to Genre. UK: Metropolitan East Disadvantaged Schools' Program.

Creswell, J. W. (2014). Research Design: Qualitative, Quantitative, and Mixed Methods Approaches (4th ed.). UK: SAGE.

Douglas, B. H., \& Heekyeong, L. (2015). Teaching by Principles: An Interactive Approach to Language Pedagogy (4th ed.). San Francisco: Pearson Education.

Elliott, A. C., \& Woodward, W. A. (2007). Statistical Analysis Quick Reference Guidebook (1st 
ed.). UK: SAGE.

Field, A. (2009). Discovering Statistics Using SPSS. UK: SAGE Publications. Retrieved from https://books.google.co.id/books?id=a6FLF1YOqtsC\&dq=Field,+John+W.+(2009).+Dis covering+Statistics+Using+SAS\&hl=id\&sa=X\&ved=0ahUKEwj_PGhzM_bAhWDtI8KHcm_AU4Q6AEIJzAA

Fraenkal, J. R., Norman E. Wallen, and H. H. H. (2012). Content analysis." How to design and evaluate research in education (8th ed.). New York: McGraw-Hill.

Harmer Jeremy. (2015). The Practice of English Language Teaching. UK: Pearson Education.

Hatch, E., \& Farhady, H. (1982). Research design and statistics for applied linguistics. Newbury House.

Kaswan,\&Suprijadi, D. (2016). Research in English Language Education (2nd ed.). Bandung: Putra Praktisi.

Lie, A. (2007). Cooperative learning, mempraktekan cooperative learning di ruang-ruang kelas (2nd ed.). Jakarta: PT. Gramedia.

McGrath, I. (2016). Materials Evaluation and Design for Language Teaching (2nd ed.). Edinburgh University: Edinburgh University Press. 